\title{
The hedgehog-patched signaling pathway and function in the mammalian ovary: a novel role for hedgehog proteins in stimulating proliferation and steroidogenesis of theca cells
}

\author{
Leon J Spicer, Satoko Sudo ${ }^{1}$, Pauline Y Aad, Lora Shuo Wang ${ }^{1}$, Sang-Young Chun ${ }^{1}$, \\ Izhar Ben-Shlomo ${ }^{1}$, Cindy Klein ${ }^{1}$ and Aaron J W Hsueh ${ }^{1}$ \\ Department of Animal Science, Oklahoma State University, 114 Animal Science Building, Stillwater, Oklahoma \\ 74078, USA and ${ }^{1}$ Division of Reproductive Biology, Department of Obstetrics and Gynecology, Stanford University \\ School of Medicine, Stanford, California 94305-5317, USA
}

Correspondence should be addressed to L J Spicer; Email: leon.spicer@okstate.edu

L J Spicer and S Sudo contributed equally to this work

\begin{abstract}
The expression of hedgehog $(\mathrm{Hh})$ genes, their receptor, and the co-receptor in mice, rat, and bovine ovaries were investigated. RT-PCR of ovarian transcripts in mice showed amplification of transcripts for Indian (Ihh) and desert (Dhh) Hh, patched 1 (Ptch1), and smoothened (Smo) genes. Semi-quantitative RT-PCR and northern blot analyses showed that whole ovarian Ihh and Dhh transcripts decreased 4-24 h after hCG versus 0-48 h after pregnant mares serum gonadotrophin treatment in mice, whereas mouse Ptch1 and Smo transcripts were expressed throughout the gonadotropin treatments. Quantitative real-time RT-PCR (qRT-PCR) revealed that the expression of the Hh-patched signaling system with Ihh mRNA abundance in granulosa cells was greater, whereas Smo and Ptch1 mRNA abundance was less in theca cells of small versus large follicles of cattle. In cultured rat and bovine theca-interstitial cells, qRT-PCR analyses revealed that the abundance of Gli1 and Ptch1 mRNAs were increased $(P<0.05)$ with sonic hedgehog $(\mathrm{SHH})$ treatment. Additional studies using cultured bovine theca cells indicated that SHH induces proliferation and androstenedione production. IGF1 decreased Ihh mRNA abundance in bovine granulosa cells. The expression and regulation of $\boldsymbol{I h h}$ transcripts in granulosa cells and Ptch1 mRNA in theca cells suggest a potential paracrine role of this system in bovine follicular development. This study illustrates for the first time $\mathrm{Hh}$ activation of Gli1 transcriptional factor in theca cells and its stimulation of theca cell proliferation and androgen biosynthesis.

Reproduction (2009) 138 329-339
\end{abstract}

\section{Introduction}

The hedgehog $(\mathrm{Hh})$ family of proteins was first cloned in Drosophila (Hammerschmidt et al. 1997), and its signaling pathway is highly conserved during evolution (Ingham \& McMahon 2001, Lum \& Beachy 2004, Wang et al. 2007). The Hh signaling pathway is triggered by the stoichiometric binding of $\mathrm{Hh}$ ligand to its receptor, patched 1 (PTCH1; Marigo et al. 1996, Stone et al. 1996, Fuse et al. 1999). In the absence of $\mathrm{Hh}$ protein, PTCH1 suppresses the constitutive activity of smoothened (SMO), the seven transmembrane G-protein-coupled co-receptor (Taipale et al. 2002). The secreted $\mathrm{Hh}$ protein inactivates the actions of PTCH1 expressed in adjacent cells (Ingham \& McMahon 2001). Inactivation of PTCH1 following binding with the $\mathrm{Hh}$ protein removes the inhibition on the activity of SMO (Taipale et al. 2002, Gulino et al. 2007, di Marcotullio et al. 2007), and allows the activation of Gli1, a latent cytoplasmic transcription factor (GLI1, the mammalian homolog to Drosophila $\mathrm{Ci}$ protein), leading to the induction of target gene expression (Ingham \& McMahon 2001, Lum \& Beachy 2004). In mammals, three $\mathrm{Hh}$ proteins, Indian (IHH), desert $(\mathrm{DHH})$, and sonic $(\mathrm{SHH})$ hedgehog, are capable of binding to PTCH1 leading to signal transduction via derepression of the co-receptor, SMO (Ingham \& McMahon 2001, Lum \& Beachy 2004, Wang et al. 2007). All three $\mathrm{Hh}$ proteins bind to PTCH1 with equal affinity (Pathi et al. 2001) and have been used interchangeably to invoke biological responses (Vortkamp et al. 1996, Krishnan et al. 2001, Zhang et al. 2001, Deckelbaum et al. 2002). Hh proteins are expressed at epithelial-mesenchymal boundaries in several developing organs to activate PTCH1, essential for the growth, differentiation, and morphogenesis of the lung, gut, pancreas, hair follicle, and tooth (Ingham \& McMahon 2001, Taipale et al. 2002, Lum \& Beachy 2004). 
Although originally found to be important during embryonic development, recent studies have demonstrated the importance of the $\mathrm{Hh}$ signaling in many tissues during postnatal life. Extensive genetic and molecular evidence indicates that $\mathrm{SHH}$ controls the proliferation and differentiation of cells in the central and peripheral nervous systems, skin, limbs, and gut (Ingham \& McMahon 2001, Lum \& Beachy 2004, Wang et al. 2007). In addition, $\mathrm{IHH}$ has been implicated in the growth and differentiation of cartilage, yolk sac endoderm development, and hematopoiesis in mice (Belaoussoff et al. 1998, St-Jacques et al. 1999, Dyer et al. 2001). In reproductive processes in mice, $\mathrm{DHH}$ is required for the development of the testis (Pierucci-Alves et al. 2001, Yao et al. 2002), whereas IHH plays a crucial role in implantation during the early stages of pregnancy (Matsumoto et al. 2002, Takamoto et al. 2002, Lee et al. 2006). However, the role of $\mathrm{Hh}$ signaling in regulating reproduction of monotocous mammals such as cattle has not been studied.

Recently, the Hh system has been shown to be present in the mouse ovary (Wijgerde et al. 2005, Russell et al. 2007). Specifically, Hh target genes Ptch1 (i.e. Hh receptor) and Gli1 (i.e. an $\mathrm{Hh}$ activated transcription factor) are primarily expressed in theca cells, whereas Ihh and Dhh mRNAs are predominately located in granulosa cells (Wijgerde et al. 2005). Immunostaining of PTCH1 was found in both theca and granulosa cells of mice and $\mathrm{SHH}$-stimulated mitosis of granulosa cells in vitro (Russell et al. 2007), but the potential role of $\mathrm{Hh}$ proteins in the ovary, and in particular theca cells, remains unclear. Moreover, the ovarian expression of genes of the Hh signaling pathway has not been evaluated in monotocous species. Therefore, we evaluated: 1) the expression and hormonal regulation of $/ \mathrm{hh}$ in granulosa cells and its receptor Ptch1 in theca cells in both rat and bovine ovaries; 2) whether follicle size is associated with changes in Ptch 1 mRNA in theca and $I h h$ mRNA in theca and granulosa cells; 3) whether treatment with $\mathrm{SHH}$ stimulated the expression of the Gli1 transcription factor in cultured theca cells in rats and cattle; and 4) whether treatment of cultured theca cells with $\mathrm{SHH}$ alters their proliferation and/or androgen biosynthesis.

\section{Results \\ Mouse and rat ovarian expression and gonadotropin regulation of $\mathrm{Hh}$, Ptch1 and Smo genes}

To elucidate the expression of $\mathrm{Hh}$, Ptch 1 and Smo transcripts and to monitor their regulation by gonadotropins, semi-quantitative RT-PCR was performed using ovarian cDNAs from ovaries of mice treated with gonadotropins. As shown in Fig. 1, treatment with pregnant mares serum gonadotrophin (PMSG) caused
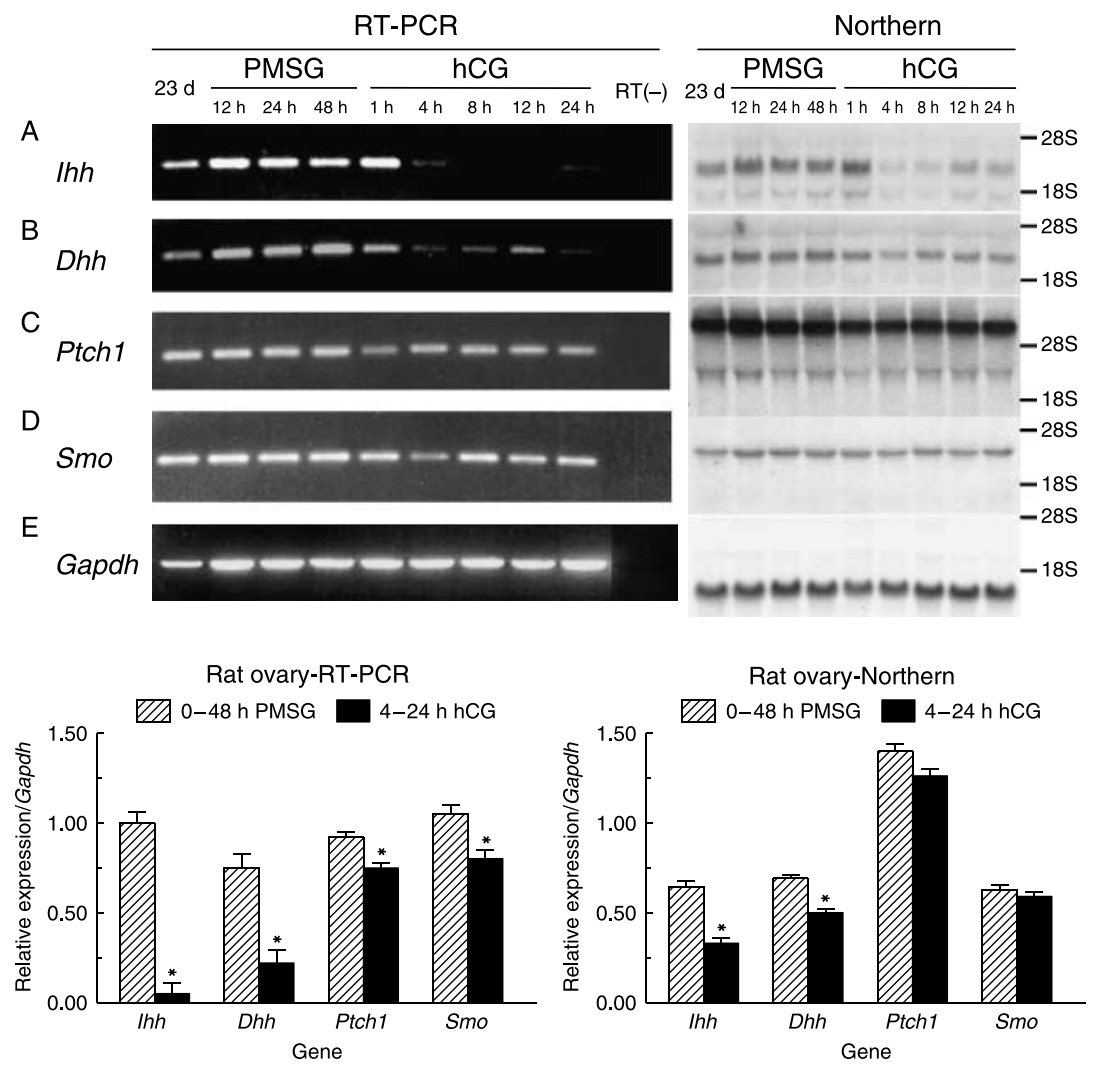

Figure 1 Expression of (A) Ihh, (B) Dhh, (C) Ptch1, (D) Smo, and (E) Gapdh in ovaries of gonadotropintreated mice using RT-PCR and northern analyses. Ovarian RNA was extracted at different times after hormonal treatment before RT-PCR or northern blot analyses. Day 23 (23 d) is equivalent to $0 \mathrm{~h}$ prior to PMSG. Gapdh expression served as an internal control as described in Materials and Methods. The experiments for each gene were repeated thrice for $I h h$, Dhh, and Gapdh, and twice for Ptch1 and Smo. Representative results are shown from RNA pooled from two to three mice for RT-PCR and northern analysis. Bottom panels: band density was analyzed for $0-48 \mathrm{~h}$ post-PMSG and $4-24 \mathrm{~h}$ post-hCG treatment, and expressed abundance normalized to Gapdh mRNA band intensity; asterisk $(*)$ indicates mean differs $(P<0.05)$ from its respective $0-48 \mathrm{~h}$ post-PMSG value. 
little change in Ihh mRNA abundance. Following hCG treatment, whole ovarian Ihh mRNA abundance appeared to decrease within 4-h post-hCG and was 95\% lower $(P<0.05) 4-24$ h post-hCG versus $0-24$ postPMSG (Fig. 1). A similar trend (75\% decrease) was found for whole ovarian Dhh mRNA abundance (Fig. 1). Regulation of Ptch1 and Smo mRNA abundance by gonadotropins was less dramatic with Ptch1 and Smo mRNA abundance 19 and 24\% lower 4-24 h post-hCG than $0-48 \mathrm{~h}$ post-PMSG. These results suggest that the ligands of the Hh signaling system may be regulated by gonadotropins, but expression levels of receptor and co-receptor showed minimal changes. By contrast, other paralogs of Hh (Shh) and patched (Ptch2) could not be amplified under the same conditions (data not shown).

To extend the RT-PCR data, northern blot analyses were performed to further analyze the expression and regulation of mRNA levels for $I h h, D h h, P t c h 1$, and Smo (Fig. 1). The sizes of major transcripts for $I h h, D h h$, Ptch1, and Smo in rat ovaries were 2.5, 2.5, 7.9, and $3.7 \mathrm{~kb}$ respectively, consistent with earlier findings in other tissues (Goodrich et al. 1997, Traiffort et al. 1998). Similar to RT-PCR results, semi-quantitative whole ovarian $I h h$ and Dhh mRNA abundance was 48 and $27 \%$ lower $(P<0.05)$ respectively, $4-24 \mathrm{~h}$ post-hCG than $0-40 \mathrm{~h}$ post-PMSG treatment. By contrast, whole ovarian Ptch1 and Smo mRNA abundance did not appear to change.

\section{Bovine ovarian expression and developmental regulation of $\mathrm{Hh}, \mathrm{PTCH} 1$ and SMO genes}

To investigate the ovarian cell types expressing $I H H$, PTCH1, and SMO mRNA in small and large follicles, quantitative real-time RT-PCR (qRT-PCR) analyses were performed on granulosa and theca cells collected from two sizes of bovine follicles (Fig. 2). Theca cell PTCH1 (Fig. 2A) and $S M O$ (Fig. 2B) mRNA levels were greater $(P<0.05)$ in large follicles than small follicles. Also, PTCH1 and SMO mRNAs were detectable in granulosa cells but at a much lower abundance than in theca cells, and did not differ between small and large follicles. The ligand $I H H$ mRNA abundance was the greatest $(P<0.05)$ in small-follicle granulosa cells and similar in largefollicle theca and granulosa cells (Fig. 2C).

\section{Regulation of the expression of Gli1 transcriptional factor and Ptch1 receptor in cultured rat theca-interstitial cells}

To study the functional importance of PTCH1 in theca interna of rats, we isolated theca-interstitial cells and treated them with a recombinant amino-terminal peptide of mouse SHH (Matsumoto et al. 2002). This mature region of $\mathrm{SHH}$ is $91 \%$ identical to the corresponding region of $\mathrm{IHH}$ and binds to PTCH1 with similar affinity (Zhang et al. 2001, Matsumoto
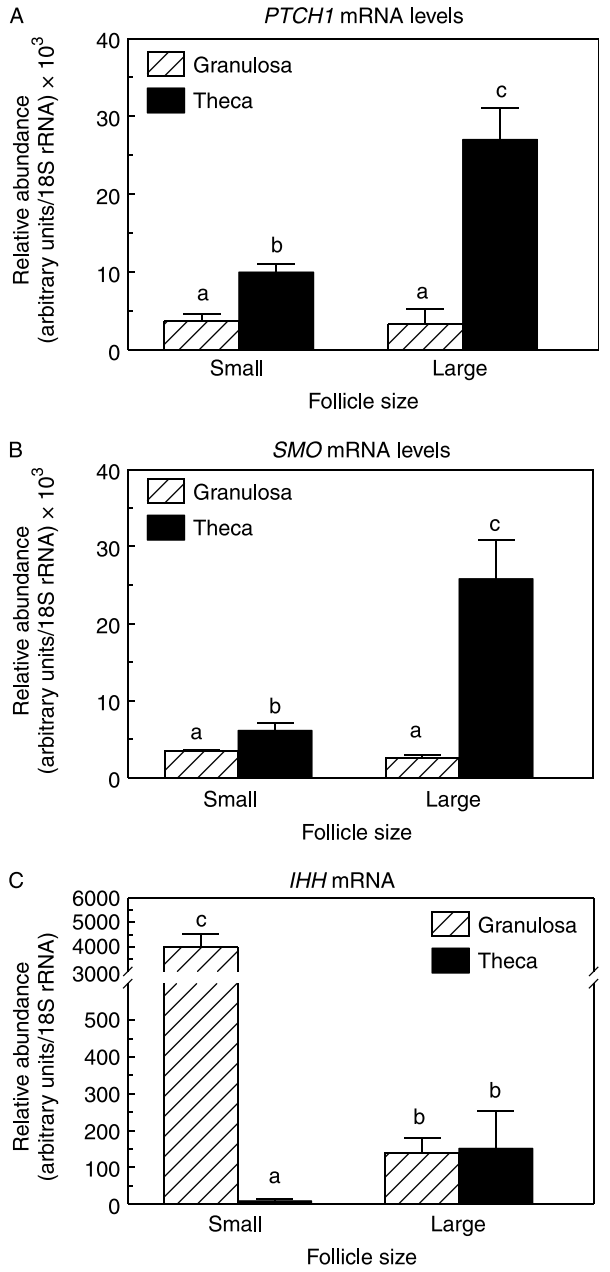

Figure 2 Effect of the size of follicle on the abundance of granulosa and theca cell PTCH1 (hedgehog receptor; (A)), SMO (the hedgehog co-receptor; (B)) and $I H H(C)$ mRNA in bovine follicles. Granulosa and theca cells from small $(2-6 \mathrm{~mm})$ and large $(8-22 \mathrm{~mm})$ follicles were collected, RNA isolated, and qRT-PCR used to quantify mRNA levels. Values are normalized to constitutively expressed $18 \mathrm{~S}$ rRNA. ${ }^{\mathrm{a}, \mathrm{b}, \mathrm{c}}$ Means $(n=6)$ without a common superscript differ $(P<0.05)$.

et al. 2002). Treatment (24 h) with SHH stimulated the transcript level for Gli1 in a dose-dependent manner with $1000 \mathrm{ng} / \mathrm{ml}$ leading to >37-fold increases (Fig. 3). Although requiring higher doses, treatment with $1000 \mathrm{ng} / \mathrm{ml} \mathrm{SHH}$ also stimulated the expression of Ptch1 mRNA leading to a 1.9-fold increase in its abundance (Fig. 3). By contrast, SHH treatment did not alter the transcript levels for Gli2 and Gli3 (Fig. 3).

\section{Hh regulation of the expression of GLI1 transcriptional factor and PTCH1 receptor in cultured bovine theca cells}

In bovine theca cells cultured in the presence of $10 \mathrm{ng} / \mathrm{ml}$ insulin-like growth factor-I (IGF1) and $10 \mathrm{ng} / \mathrm{ml} \mathrm{LH}$, treatment of $1000 \mathrm{ng} / \mathrm{ml} \mathrm{SHH}$ for $5 \mathrm{~h}$ increased $(P<0.05) \quad P T C H 1$ and GLI1 mRNA 

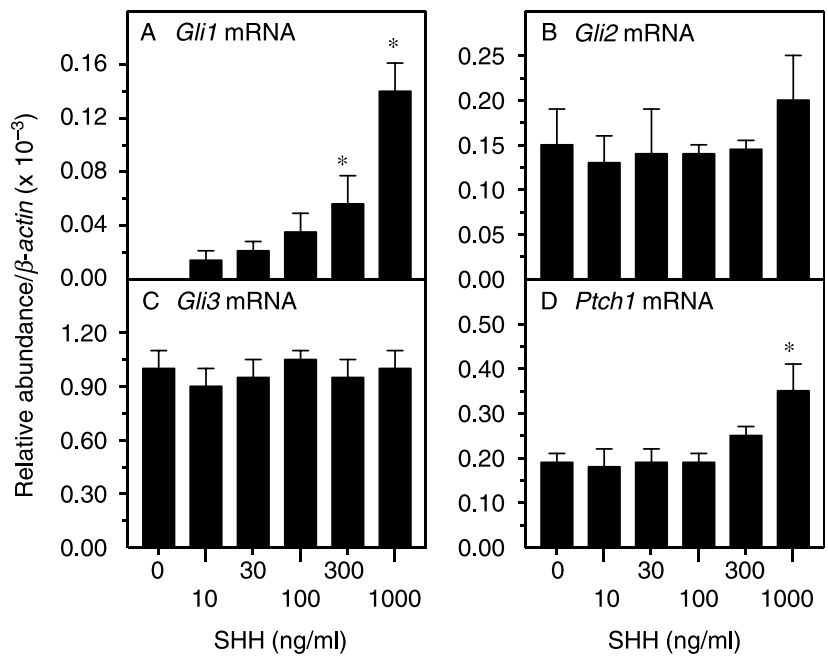

Figure 3 Regulation of Gli transcriptional factor and Ptch1 expression by recombinant mouse $\mathrm{SHH}$ amino terminal peptide $(\mathrm{SHH})$ in cultured rat theca-interstitial cells. Enriched theca-interstitial cells $(1-2 \times 105$ cells $/ 500 \mu \mathrm{l}$ ) were obtained from ovaries of at least ten rats following a Percoll discontinuous density centrifugation procedure and incubated in McCoy 5A medium supplemented with $10 \%$ FBS for $3 \mathrm{~h}$. Media were then replaced by the serum-free McCoy $5 \mathrm{~A}$ medium, and cells were incubated for $24 \mathrm{~h}$ with or without increasing doses of SHH. After washing with PBS twice, cells were harvested to extract RNA, before determination of transcript levels for different genes by using qRT-PCR. (A) Gli1, (B) Gli2, (C) Gli3, and (D) Ptch1. Mean \pm s.D. of triplicates from four experiments. ${ }^{*} P<0.05$ versus respective control $(0 \mathrm{ng} / \mathrm{ml})$.

abundance, but had no effect $(P>0.10)$ on the abundance of $S M O$ mRNA (Fig. 4A). Also, the levels of LHCGR, CYP11A1, and CYP17A1 mRNA were not affected ( $P>0.10$ ) by $1000 \mathrm{ng} / \mathrm{ml} \mathrm{SHH} \mathrm{(Fig.} \mathrm{4B).}$

\section{Hh regulation of proliferation and steroidogenesis of bovine theca cells}

SHH increased $(P<0.05)$ IGF1-induced numbers of theca cells from small (by 21\%) and large (by 37\%) follicles (Fig. 5). In the absence of IGF1, SHH also increased (by $21 \% ; P<0.05$ ) the numbers of theca cells from large follicles but had no effect $(P>0.10)$ on the numbers of theca cells from small follicles (Fig. 5B). In addition, treatment of bovine theca cells from large follicles with $10 \mathrm{ng} / \mathrm{ml}$ IGF1 increased $(P<0.05){ }^{3} \mathrm{H}$-thymidine incorporation by twofold and $100 \mathrm{ng} / \mathrm{ml} \mathrm{SHH}$ had no effect $(P>0.10)$ on this response (Fig. 5C). However, $1000 \mathrm{ng} / \mathrm{ml} \mathrm{SHH}$ further increased $(P<0.05)$ IGF1-induced ${ }^{3} \mathrm{H}$-thymidine incorporation by $39 \%$ (Fig. 5C).

In cultured bovine theca cells, IGF1-induced androstenedione production was increased 19 and $32 \%$ $(P<0.05)$ by $\mathrm{SHH}(1000 \mathrm{ng} / \mathrm{ml})$ treatment in cells from large (Fig. 6A) and small (Fig. 6B) follicles respectively. $\mathrm{SHH}$ also stimulated basal androstenedione production by twofold $(P<0.05)$ in theca cells of small follicles
(Fig. 6B), but had no effect $(P>0.10)$ on basal androstenedione production by theca cells from large follicles (Fig. 6A). Progesterone production by small- and large-follicle theca cells was not affected $(P>0.10)$ by $1000 \mathrm{ng} / \mathrm{ml} \mathrm{SHH}$ (Table 1).

\section{Hormonal regulation of PTCH1 mRNA in bovine theca cells and IHH mRNA levels in bovine granulosa cells}

To determine whether PTCH1 mRNA was regulated by hormones, the ability of insulin, IGF1, and LH to alter abundance of PTCH1 mRNA was analyzed in cultured theca cells. Neither plating density nor insulin affected $(P>0.10)$ the abundance of PTCH1 mRNA in largefollicle theca cells (Table 2). Similarly, neither LH nor IGF1 affected $(P>0.10)$ abundance of $P T C H 1$ mRNA in theca cells (Table 2). By contrast, insulin increased $(P<0.05)$ LHCGR mRNA abundance by twofold (data not shown), and LH plus IGF1 increased $(P<0.05)$ CYP11A1 mRNA by 1.8-fold (data not shown).

To determine whether $I H H$ mRNA was regulated by hormones, small-follicle granulosa cells were treated with IGF1 and/or FSH for $24 \mathrm{~h}$ (Fig. 7). FSH had no effect
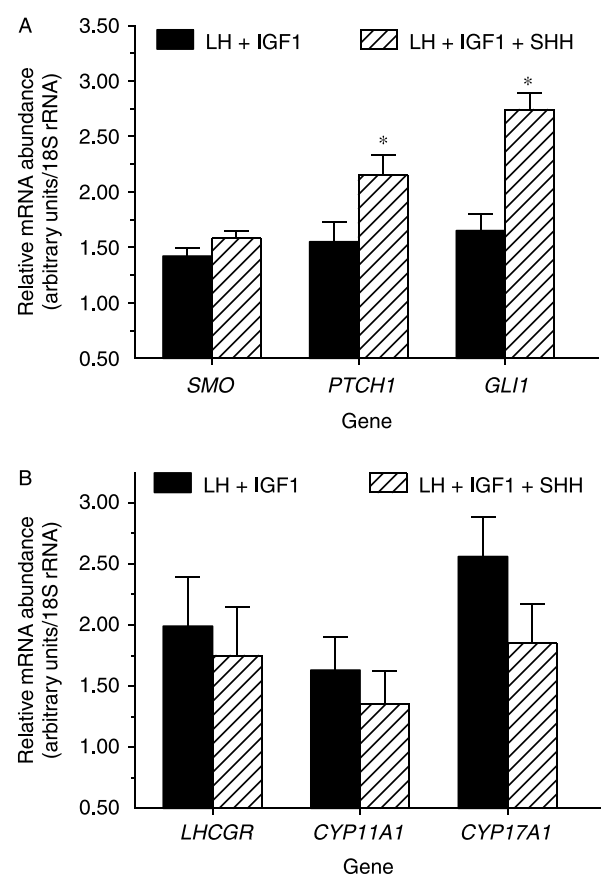

Figure 4 Effect of sonic hedgehog $(\mathrm{SHH} ; 1000 \mathrm{ng} / \mathrm{ml})$ on $S M O, P T C H 1$, GLI1, LHCGR, CYP11A1, and CYP17A1 mRNAs in bovine theca cells. Theca cells from large follicles were cultured for 2 days in the presence of $10 \%$ FCS, and then cells were washed and incubated in serum-free medium in the presence of $10 \mathrm{ng} / \mathrm{ml} \mathrm{IGF1} \mathrm{and} \mathrm{LH} \mathrm{for} 24 \mathrm{~h}$. Medium was changed and cells incubated in the absence or presence of $1000 \mathrm{ng} / \mathrm{ml} \mathrm{SHH}$ with $10 \mathrm{ng} / \mathrm{ml} \mathrm{IGF1}$ and LH for an additional $5 \mathrm{~h}$ and cellular RNA collected. Real-time qRT-PCR was used to quantify mRNA levels. Values are means of three separate experiments and normalized to constitutively express $18 \mathrm{~S}$ rRNA. *Within gene type, mean $(n=6)$ differs $(P<0.05)$ from control $(\mathrm{LH}+\mathrm{IGF} 1)$. 

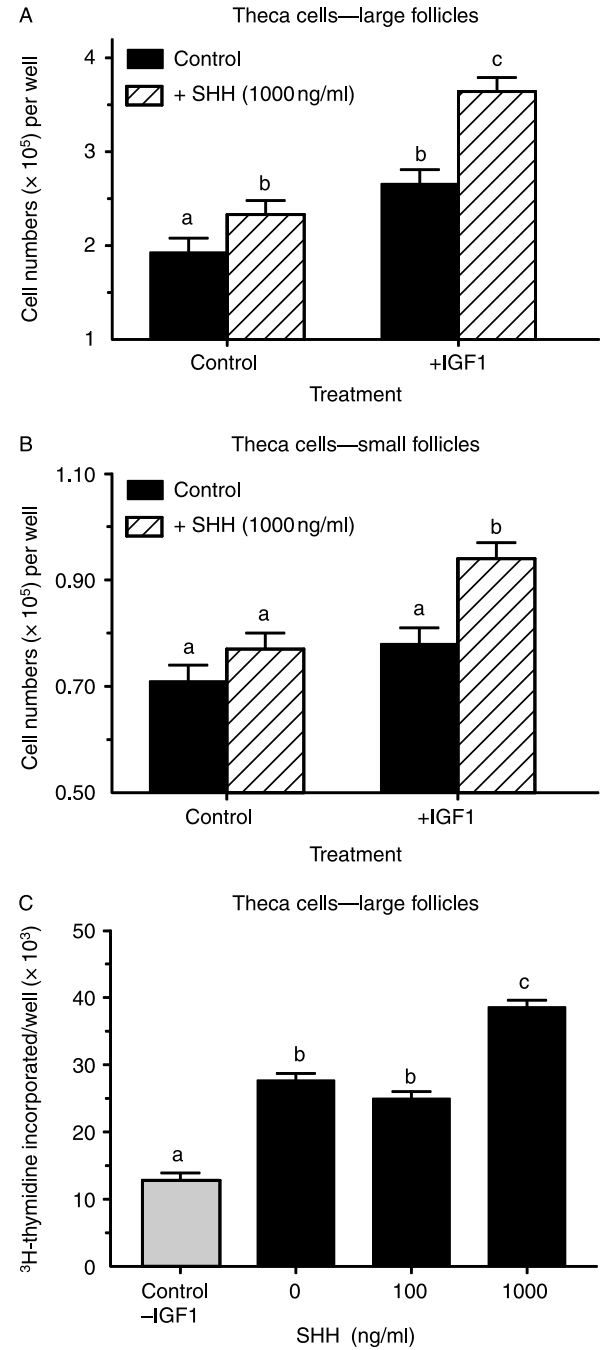

Figure 5 Effect of treatment of sonic hedgehog $(\mathrm{SHH})$ and IGF1 on bovine theca cell proliferation. (A) and (B) Theca cells from large (8-22 mm; (A)) and small (2-6 mm; (B)) follicles were cultured for 2 days in the presence of $10 \%$ FCS, and then cells were washed and incubated in serum-free medium for an additional $48 \mathrm{~h}$ in the absence or presence of $1000 \mathrm{ng} / \mathrm{ml} \mathrm{SHH}$ with $30 \mathrm{ng} / \mathrm{ml} \mathrm{IGF1}$ and $100 \mathrm{ng} / \mathrm{ml} \mathrm{LH}$. (C) Theca cells from large follicles were cultured for $48 \mathrm{~h}$ in $10 \%$ FCS, serum-starved for $24 \mathrm{~h}$ in serum-free medium, and then cultured in serum-free medium with no treatments (control) or with IGF1 (30 ng/ml, black bars) and SHH $(0,100,1000 \mathrm{ng} / \mathrm{ml})$ for $40 \mathrm{~h}$ in the presence of $1 \mu \mathrm{Ci}$ of ${ }^{3} \mathrm{H}$-thymidine to measure DNA synthesis. Values are means \pm S.E.M. of three separate experiments $(n=9)$. ${ }^{\mathrm{a}, \mathrm{b}, \mathrm{c}}$ Within a panel, means without a common superscript differ $(P<0.05)$.

$(P>0.10)$ on $I H H$ mRNA in granulosa cells, whereas IGF1 decreased $(P<0.05)$ the abundance of $I H H$ mRNA in granulosa cells (Fig. 7).

\section{Discussion}

The present study documents novel functional $\mathrm{Hh}$ signaling in theca cells of rats and cattle, and further extends previous investigations demonstrating the cellular localization of $\mathrm{Hh}$ system in mouse ovaries
(Wijgerde et al. 2005) and SHH induction of Gli1 mRNA in mouse granulosa cells (Russell et al. 2007), and GLI1 and PTCH1 mRNA in other mammalian cells (Goodrich et al. 1996, Kenney \& Rowitch 2000). Moreover, these studies demonstrated hormonal and developmental regulation of the transcripts for Ihh, Ptch1, and Smo in the rodent and bovine ovary, and discovered that $\mathrm{SHH}$ treatment stimulated proliferation of bovine theca cells and augmented androstenedione production.

For the first time, we demonstrated that Smo mRNA is not altered with Hh stimulation, and that Smo mRNA abundance in theca cells is greater in large than small follicles. Consistent with the present study, Hh treatment increases the expression of Ptch1 itself in cell types other than theca cells including mouse neuronal cells (Kenney \& Rowitch 2000) and mouse medulloblastoma cells (Briggs et al. 2008). PTCH1 is a key component of the $\mathrm{Hh}$ signaling pathway, which controls cell fate determination during development (Hammerschmidt et al. 1997). Ptch1 mutations cause derepression of target genes, cell fate changes, and excessive growth in some tissues (Ingham et al. 1991). Results of the present study identified for the first time a potential functional role of $\mathrm{SHH}$ in theca cell function (i.e. steroidogenesis and proliferation) of mammals. Effects of $\mathrm{Hh}$ proteins on steroidogenesis, although a novel finding for ovarian
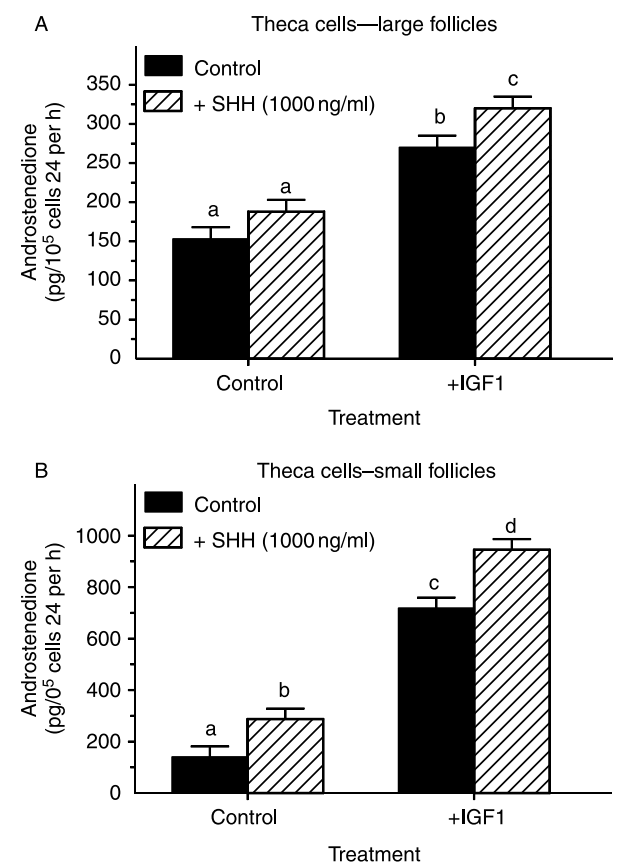

Figure 6 Effect of 2-day treatment of IGF1 and sonic hedgehog $(\mathrm{SHH})$ on bovine theca cell androstenedione production. Theca cells from large (8-22 mm; (A)) and small (2-6 mm; (B)) follicles were cultured for 2 days in the presence of $10 \%$ FCS, and then cells were washed and incubated in serum-free medium for an additional $48 \mathrm{~h}$ in the absence or presence of $1000 \mathrm{ng} / \mathrm{ml} \mathrm{SHH}$ with $30 \mathrm{ng} / \mathrm{ml} \mathrm{IGF1}$ and $100 \mathrm{ng} / \mathrm{ml} \mathrm{LH}$. Values are means \pm S.E.M. of three separate experiments $(n=9)$.

a,b Means without a common superscript differ $(P<0.05)$. 
Table 1 Effect of 2-day treatment of insulin-like growth factor-I (IGF1), sonic hedgehog $(\mathrm{SHH})$, or both on progesterone production by theca cells from small $(2-6 \mathrm{~mm})$ and large $(8-22 \mathrm{~mm})$ bovine follicles.

\begin{tabular}{lccc}
\hline $\begin{array}{l}\text { Dose of } \\
\text { IGF1 } \\
(\mathrm{ng} / \mathrm{ml})\end{array}$ & $\begin{array}{c}\text { Dose of } \\
\text { SHH } \\
(\mathrm{ng} / \mathrm{ml})\end{array}$ & $\begin{array}{c}\text { Small follicle } \\
\text { progesterone } \\
\left(\mathrm{ng} / 10^{5} \text { cells/24 } \mathrm{h}\right)\end{array}$ & $\begin{array}{c}\text { Large follicle } \\
\text { progesterone } \\
\left(\mathrm{ng} / 10^{5} \text { cells/24 h) }\right.\end{array}$ \\
\hline 0 & 0 & $17.1^{\mathrm{a}} \pm 2.0$ & $8.8^{\mathrm{a}} \pm 1.4$ \\
30 & 0 & $38.9^{\mathrm{b}} \pm 2.5$ & $17.5^{\mathrm{b}} \pm 3.5$ \\
0 & 1000 & $17.4^{\mathrm{a}} \pm 0.7$ & $8.9^{\mathrm{a}} \pm 0.9$ \\
30 & 1000 & $39.4^{\mathrm{b}} \pm 2.1$ & $16.2^{\mathrm{b}} \pm 2.7$ \\
\hline
\end{tabular}

a,b Within a column, means ( \pm S.E.M.) without a common superscript differ $(P<0.05)$.

cells, are not without precedence. In fetal Leydig cell precursors, PTCH1 signaling up-regulates P450 sidechain cleavage enzyme (CYP11A1) expression (Yao et al. 2002). Because the theca interna plays a key role in the pathology of polycystic ovarian disease, these results raise the possibility for examining a potential role of $\mathrm{Hh}$ signaling in the pathogenesis of PCOS.

The present study revealed that both rat thecainterstitial and bovine theca cells respond to $\mathrm{Hh}$ with increased Gli1 mRNA, but further study will be required to more clearly define how $\mathrm{Hh}$ proteins may regulate ovarian follicular function particularly as it pertains to monotocous (e.g. cattle) versus polytocous (e.g. rats) species. Recently, we have reported that PTCH1 mRNA in theca cells were lower in cattle selected for double versus single ovulations, suggesting that increased PTCH1 expression may be involved with the development of multiple dominant follicles (Aad et al. 2008). Because systemic and follicular fluid IGF1 are greater in cattle with double ovulations (Echternkamp et al. 2004), perhaps IGF1 regulates theca PTCH1 mRNA. However, PTCH1 mRNA abundance was unaltered by IGF1, LH, or insulin in the present study. It is possible that IGF1 decreases theca PTCH1 mRNA indirectly by reducing granulosa $\mathrm{IHH}$ production (see next section). In Drosophila, the role of Hh signaling in the adult ovary is well characterized and $\mathrm{Hh}$ was found to drive proliferation of somatic and germline stem cells (Forbes et al. 1996, Zhang \& Kalderon 2000). By contrast, a role of $\mathrm{Hh}$ signaling in the vertebrate ovary has only recently been described using in situ hybridization and immunohistochemistry in mice (Wijgerde et al. 2005, Russell et al. 2007), and results of the present study support a mitogenic role for $\mathrm{Hh}$ in bovine theca cells. Because dramatically greater abundance in SMO and PTCH1 mRNAs existed in theca cells of large than small follicles in cattle, and levels of PTCH1 and SMO mRNA in bovine granulosa cells did not differ between small and large follicles, results of the present study indicate that the theca layer may be the primary site of the $\mathrm{Hh}$ response system (i.e. PTCH1 and SMO) in the bovine ovary.

Of interest, the quantitative differential expression of ligand and receptor of the $\mathrm{Hh}-\mathrm{PTCH} 1$ signaling system in cell types of different embryonic origins as observed in the present and previous (Wijgerde et al. 2005) studies is similar to that found in the testis (Bitgood et al. 1996, Pierucci-Alves et al. 2001). Evidence indicates that $\mathrm{Hh}$ ligands secreted by epithelial cells (e.g. IHH in granulosa or DHH in Sertoli cells of the testis) interact with PTCH1 in mesenchymal cells (e.g. theca cells or Leydig cells of the testis) at their cellular boundaries in a paracrine context (Bitgood et al. 1996, Wijgerde et al. 2005). A recent study in mice has indicated that both $\mathrm{Hh}$ and its PTCH1 response system may also exist in an autocrine context within granulosa cells (Russell et al. 2007). Apparently, which ligand (i.e. $\mathrm{HHH}, \mathrm{DHH}, \mathrm{SHH}$ ) is produced is not critical because all $\mathrm{Hh}$ proteins bind to PTCH1 with similar affinities (Pathi et al. 2001) and similar biological responses (Vortkamp et al. 1996, Krishnan et al. 2001, Zhang et al. 2001, Deckelbaum et al. 2002). Our studies using sensitive gRT-PCR indicate that both granulosa and theca cells have detectable PTCH1 and SMO mRNA, but granulosa cells contain significantly less abundance than in theca cells of cattle. By contrast, granulosa and theca cells had detectable Ihh mRNA, but theca cells contained significantly less than granulosa cells of small follicles. Not previously reported for any cell type, we found that IHH mRNA abundance was suppressed by IGF1, linking the ovarian Hh system with the IGF1 system at least in cattle. As mentioned, cattle selected for double

Table 2 Lack of effect of insulin, LH, and insulin-like growth factor-I (IGF1) treatments on transcript levels for Ptch1 mRNA in large-follicle (8-22 mm) theca cells*.

\begin{tabular}{|c|c|c|c|c|c|}
\hline $\begin{array}{l}\text { Plating density } \\
\text { (cells/well) } \times 10^{5}\end{array}$ & $\begin{array}{c}\text { Duration of } \\
\text { treatment }(h)\end{array}$ & $\begin{array}{c}\text { Dose of } \\
\text { insulin }(\mathrm{ng} / \mathrm{ml})\end{array}$ & $\begin{array}{c}\text { Dose of } \\
\mathbf{L H}(\mathrm{ng} / \mathrm{ml})\end{array}$ & $\begin{array}{c}\text { Dose of } \\
\text { IGF1 (ng/ml) }\end{array}$ & $\begin{array}{c}\text { Ptch1 } \text { mRNA (relative } \\
\text { abundance) }\end{array}$ \\
\hline 1 & 24 & 0 & 0 & 0 & $1.5 \pm 0.2$ \\
\hline 1 & 24 & 100 & 0 & 0 & $2.2 \pm 0.5$ \\
\hline 3 & 24 & 0 & 0 & 0 & $1.5 \pm 0.1$ \\
\hline 3 & 24 & 100 & 0 & 0 & $1.7 \pm 0.1$ \\
\hline 2 & 24 & 0 & 0 & 0 & $2.8 \pm 0.6$ \\
\hline 2 & 24 & 0 & 0 & 30 & $2.2 \pm 0.5$ \\
\hline 2 & 24 & 0 & 30 & 0 & $2.4 \pm 0.3$ \\
\hline 2 & 24 & 0 & 30 & 30 & $2.2 \pm 0.3$ \\
\hline 1 & 48 & 0 & 30 & 0 & $1.5 \pm 0.2$ \\
\hline 1 & 48 & 0 & 30 & 30 & $1.5 \pm 0.2$ \\
\hline
\end{tabular}

*No significant $(P>0.10)$ treatment effects were observed (means \pm S.E.M). 


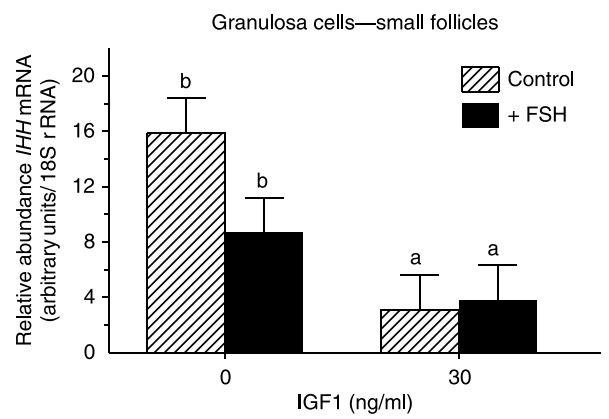

Figure 7 Effect of FSH and IGF1 treatments on transcript levels for $I H H$ mRNA in small-follicle granulosa cells of cattle. Small-follicle (2-6 mm) granulosa cells of cattle were treated for $24 \mathrm{~h}$ with the indicated treatments in serum-free medium and the various mRNAs were quantified by qRT-PCR as described in Materials and Methods. ${ }^{\mathrm{a}, \mathrm{b}}$ Means ( \pm S.E.M.) without a common letter differ $(P<0.05)$. Relative mRNA abundance was normalized to constitutively expressed $18 \mathrm{~S}$ rRNA and expressed in arbitrary units from three replicate experiments $(n=6)$.

ovulations versus single ovulations have greater IGF1 levels in blood and follicular fluid and have recently been reported to contain lower amounts of PTCH1 mRNA in theca cells (Aad et al. 2008). Thus, IGF1 may indirectly reduce theca PTCH1 by reducing granulosa $\mathrm{IHH}$ production. In mice, qualitative RT-PCR and northern analyses revealed that ovarian $I h h$ and Dhh mRNA abundance was down-regulated by hCG. Furthermore, research will be required to resolve the paracrine versus autocrine context by which the $\mathrm{Hh}$ system operates within the ovarian follicle of various mammals as well as clarify the species differences that may exist in terms of hormonal regulation of the Hh system.

It is known that the Dhh-null male mice lack mature sperm (Bitgood et al. 1996). On select hybrid backgrounds, Dhh-null mice also exhibited discrete defects in testis organization, including abnormal development of peritubular myoid cells, apolar Sertoli cells, absence of basal lamina, and anastomotic testis cords (Pierucci-Alves et al. 2001, Park et al. 2007). Defects in adult Leydig cell differentiation were also reported (Clark et al. 2000). Studies have indicated that high levels of $\mathrm{thh}$ expression in granulosa cell tumors of mice overexpress a long acting gonadotropin (Owens et al. 2002), and that SHH increases mouse granulosa cell proliferation in vitro (Russell et al. 2007). Thus, the ovarian $\mathrm{Hh}$ signaling system could be involved in the proliferation of granulosa cells under certain conditions. In bovine theca cells where PTCH1 mRNA predominates, $\mathrm{SHH}$ stimulated theca cell proliferation and androstenedione production in cells from large and small follicles, but whether alterations in the Hh system could alter theca interna development or induce theca cell pathogenesis such as PCOS will require further study. Also, further studies using conditional deletion of the Ihh or Ptch1 gene in the ovary could reveal the exact paracrine or autocrine role of Hh signaling during follicle development.
In conclusion, the expression and regulation of $\mathrm{IHH}$ transcripts in granulosa cells and PTCH1 mRNA in theca cells suggest a potential paracrine role of this system in bovine follicular development. These studies illustrate, for the first time, $\mathrm{Hh}$ stimulation of theca cell proliferation and androgen biosynthesis.

\section{Materials and Methods \\ Biological materials and cell culture}

\section{Mouse and rat tissues}

To investigate the expression and regulation of ligands and receptors of the $\mathrm{Hh}$ system in the ovary, 23-day-old female Swiss-Webster mice were obtained from Charles River Breeding Laboratories (Wilmington, MA, USA), and injected with $4 \mathrm{IU}$ of PMSG (Calbiochem, San Diego, CA, USA) s.c., followed by $10 \mathrm{IU}$ of hCG (Sigma Chemical Co.) i.p. $48 \mathrm{~h}$ later. Animals were housed in accordance with institutional and $\mathrm{NIH}$ guidelines for the care and use of experimental animals.

Theca-interstitial cells were prepared from 28- to 29-day-old female Sprague-Dawley rats as previously described (Ohnishi et al. 2001). Individual ovaries were cut into four to six pieces, and many granulosa cells and oocytes were removed following needle puncture in L-15 Leibovitz medium (Life Technologies Inc.) to enrich theca-interstitial cells. Ovaries were incubated for $60 \mathrm{~min}$ at $37^{\circ} \mathrm{C}(0.25 \mathrm{ml} /$ ovary $)$ in $2.5 \mathrm{mg} / \mathrm{ml}$ collagenase (type I; Sigma Chemical Co.) and $100 \mu \mathrm{g} / \mathrm{ml}$ DNase I (Roche Diagnostics Corp). The incubated ovaries were pipetted every $30 \mathrm{~min}$ and dispersed cells were washed thrice with L-15 Leibovitz medium (Life Technologies Inc.) and passed through cell strainers of $40 \mu \mathrm{m}$ pore size (Becton Dickinson Labware, Franklin Lakes, NJ, USA). Theca-interstitial cells were then purified by a modified discontinuous density centrifugation procedure with 42 and 56\% Percoll (Ohnishi et al. 2001) in $17 \times 100 \mathrm{~mm}$ polystyrene Falcon tubes. Dispersed cells were layered on top of the Percoll and centrifuged at $400 \mathrm{~g}$ for $30 \mathrm{~min}$ at $4{ }^{\circ} \mathrm{C}$. After centrifugation, the theca-interstitial cells were collected from the interface between 42 and $56 \%$ Percoll layers.

\section{Bovine tissues}

Ovaries of cattle obtained at slaughter from a nearby abattoir were brought to the laboratory on ice and processed as previously described for obtaining theca and granulosa cells from small (2-6 mm) and large $(8-22 \mathrm{~mm})$ follicles (Spicer \& Chamberlain 1998, Spicer et al. 2008). Purity of these bovine theca cell preparations is $\geq 95 \%$ (Spicer et al. 2008). These follicle size categories were selected because: 1) previous studies indicate that granulosa cells from small follicles are less responsive to $\mathrm{FSH}$ and IGF1 than are cells from large follicles (Spicer \& Chamberlain 1998, Spicer et al. 2002), 2) the observations that follicles larger than $8 \mathrm{~mm}$ have much greater $\mathrm{E}_{2}$ concentrations than small follicles (Spicer et al. 1986, 2001, Stewart et al. 1996), 3) follicles that are destined to ovulate average $10 \pm 2 \mathrm{~mm}$ surface diameter (Marion et al. 1968), and 4) selection of the dominant follicle occurs at about $8 \mathrm{~mm}$ in diameter (Ginther et al. 2000). 


\section{RT-PCR and northern blotting of mouse and rat tissue RNA}

Total RNA from mouse ovaries was isolated using the RNeasy Mini kit (Qiagen). Samples were transcribed into cDNAs using Omniscript Reverse Transcriptase (Qiagen) and oligo(dT) $)_{12-18}$ (Invitrogen Co). Transcripts of different genes were amplified using primers as follows; Ihh (209 bp): 5'-TATCACCACCTCAGACCGTGAC- $3^{\prime}$ and $5^{\prime}$-ACCCGGTCTCCTGGCTTTACAG- $3^{\prime}$, Dhh (209 bp): 5'-AGCCGGATTCGACTGGGTCTAC-3' and 5'-GGTCCAGGAAGAGCAGCACTG-3', Shh (290 bp): 5'-CCACTGTTCTGTGAAAGCAGAG-3' and 5'-CAGCGTCTCGATCACGTAGAAG-3', Ptch1 (210 bp): 5'-CCATACACCAGCCACAGCTTCG-3' and 5'-GGAGGCTGGAGTCTGAGAACTG-3', Ptch2 (231 bp): 5'-CCAGCAGCCAGCATGTAGTCAC-3' and 5'-CTCGTGTCTGGAGCAGTAAAGG-3', Smo (210 bp): $5^{\prime}$-CTGACTGGCGGAACTCCAATCG- $3^{\prime}$ and 5'-CAGACTACTCCAGCCATCAAGG-3', glyceraldehyde-3-phosphatedehydrogenase (Gapdh; 983 bp): 5'-TGAAGGTCGGTGTGAACGGATTTGGC-3' and 5'-CATGTAGGCCATGAGGTCCACCAC- $3^{\prime}$ as an internal control. The only primers that spanned exon-exon junctions were the Shh primers. PCRs were performed for 25-35 cycles at $94{ }^{\circ} \mathrm{C}$, $30 \mathrm{~s}$ for denaturation; $62{ }^{\circ} \mathrm{C}$, $30 \mathrm{~s}$ for annealing, and $72{ }^{\circ} \mathrm{C}, 45 \mathrm{~s}$ for elongation. The PCR products were analyzed on $1.5 \%$ agarose gels stained with ethidium bromide. Amplicons were subcloned into pGEM-T easy vector (Promega Corp.), and used as probes for northern blot analyses. Northern blotting was performed as described previously (Chun et al. 2001) using ${ }^{32} \mathrm{P}$-labeled probes for mouse Ihh, Dhh, Ptch1, and Smo gene fragments derived from RT-PCR and verified based on DNA sequencing. For data normalization, blots were stripped by boiling in $0.1 \times$ SSC and $0.5 \%$ SDS for 30 min before reprobing with a cDNA probe for mouse Gapdh.

\section{Rat theca-interstitial cell culture and qRT-PCR for Gli transcription factors and Ptch1}

Theca-interstitial cells were washed thrice with McCoy's 5A medium (Life Technologies Inc.) and cell viability ( $\sim 90 \%)$ determined using trypan blue exclusion. After culturing under different conditions with or without recombinant mouse $\mathrm{SHH}$ amino-terminal peptide $(\mathrm{SHH}$; R\&D Systems, Inc., Minneapolis, MN, USA), cDNA preparations were derived from theca-interstitial cells. For qRT-PCR, rat Gli1, Gli2, Gli3, Ptch1, and $\beta$-actin cDNAs were amplified using the QuantiTect Probe PCR Kit (Qiagen), and analyzed using the Smart Cycler II System (Cepheid, Sunnyvale, CA, USA). Webtool Primer3 (http://www.broad.mit.edu/cgi-bin/primer/primer3_www.cgi) was used for designing PCR primers and probes. Primers and Taqman probes are as follows: Gli1: 5'-AGCTCCTGTGTAATTACGTTCAGTC-3', 5'-GGCTCTGACTAACTTGAGAACCTC$3^{\prime}$, and 5'-6-FAM-CAACCAGGAACTTCCATATCAGAGCCTAMRA-3'; Gli2: 5'-AAGCCTGCTCCACAATCTCTC-3', 5'-AACTTGTTCTCTTCAGCCAAGC-3', and 5'-6-FAM-AGAATTCCTCACGCCTCACCACAC-TAMRA-3'; Gli3: 5'-GACCAG CACAGTTGACAGCTT-3', 5'-CCAGATTAGGCTGGTATGGTC$3^{\prime}$, and 5'-6-FAM-AGTCATGACCTAGAAGGCGTGCAGATAMRA-3'; Ptch1: 5'-GACTCCGAGTACAGCTCTCAGAC-3',
5'-CTGTGGCTTCCACAATCACTT-3', and 5'-6-FAM-CAGTGAGGAGCTCAGGCACTATGAA-TAMRA- ${ }^{\prime}$; and $\beta$-actin: 5'-GGACCTGACGGACTACCTCATG-3'; $5^{\prime}$-TCTTTGATGTCACGCACGATTT-3', and 5'-FAM-CCTGACCGAGCGTGGCTACAGCTTC-TAMRA-3' as an internal control. None of the rat primers spanned exon-exon junctions. Thermal cycling condition was $95^{\circ} \mathrm{C}$ for 15 min followed by 40 cycles at $94{ }^{\circ} \mathrm{C}$ for $15 \mathrm{~s}$ and $60^{\circ} \mathrm{C}$ for $60 \mathrm{~s}$.

\section{Bovine theca cell culture and qRT-PCR for GLI1, PTCH1, and SMO}

To determine the developmental changes in the Hh signaling system, cells were collected as described earlier except that cells were not cultured and immediately after isolation, cells were lysed with TRIzol and frozen for later extraction of RNA (see below).

To determine the effect of $\mathrm{SHH}$ on the abundance of GLI1, PTCH1, and SMO mRNAs, theca cells were isolated from large follicles as previously described (Stewart et al. 1995, Spicer \& Francisco 1997, Spicer \& Chamberlain 1998, Spicer et al. 2008). Briefly, medium was a 1:1 mixture of DMEM and Ham F12 containing gentamicin, glutamine, and sodium bicarbonate (Sigma Chemical Co.) and $2 \times 10^{5}$ viable cells were seeded in plastic 24-well plates containing $1 \mathrm{ml}$ of $10 \%$ FCS medium. Prior to plating, cells were resuspended in medium containing $1.25 \mathrm{mg} / \mathrm{ml}$ collagenase and $0.5 \mathrm{mg} / \mathrm{ml}$ DNase. Cultures were kept at $38.5{ }^{\circ} \mathrm{C}$ in a $95 \%$ air-5\% $\mathrm{CO}_{2}$ atmosphere, and for all experiments medium was changed every $24 \mathrm{~h}$. After the 2-day plating period, this culture system utilizes serum-free medium so that specific effects of growth factors can be ascertained; LH has little or no effect alone but when concomitantly treated with insulin or IGF1, LH consistently stimulates steroidogenesis (Stewart et al. 1995, Spicer \& Francisco 1997, Spicer \& Chamberlain 1998, Spicer et al. 2008).

After the 48-h plating period, cells were washed twice with $0.5 \mathrm{ml}$ serum-free medium, and treated for an additional $24 \mathrm{~h}$ with $10 \mathrm{ng} / \mathrm{ml} \mathrm{IGF1} \mathrm{(recombinant} \mathrm{human} \mathrm{IGF1;} \mathrm{R \& D} \mathrm{Systems)}$ and ovine LH (NIDDK-oLH-26; activity: 1.0 XNIH-LH-S1 U/mg; National Hormone \& Pituitary Program, Torrance, CA, USA) in serum-free medium to maintain theca cell phenotype. Medium was then changed and cells treated for an additional $5 \mathrm{~h}$ with 0 or $1000 \mathrm{ng} / \mathrm{ml}$ recombinant human $\mathrm{SHH}$ amino terminal peptide (R\&D Systems) in the presence of ovine $\mathrm{LH}$ $(10 \mathrm{ng} / \mathrm{ml})$ and recombinant human IGF1 $(10 \mathrm{ng} / \mathrm{ml})$ in serumfree medium. Cells were then lysed with TRIzol and frozen for later extraction of RNA (see below).

To determine the effect of $\mathrm{SHH}$ on theca cell proliferation and steroidogenesis, theca cells from small and large follicles were isolated and cultured as described earlier, and after the 48-h plating period, cells were treated for an additional $48 \mathrm{~h}$ in serum-free medium with either 0 or $1000 \mathrm{ng} / \mathrm{ml} \mathrm{SHH}$ in the presence of 0 or $30 \mathrm{ng} / \mathrm{ml} \mathrm{IGF1} \mathrm{and} 100 \mathrm{ng} / \mathrm{ml} \mathrm{LH}$. To maximize steroid production, IGF1 and LH were included in the culture medium. Medium was collected and stored at $-20{ }^{\circ} \mathrm{C}$ until RIAs previously validated in our laboratory (Stewart et al. 1995, Spicer \& Francisco 1997, Spicer \& Chamberlain 1998) were conducted to quantify progesterone and androstenedione concentrations. Numbers of cells (in the 
same wells that medium was collected) were determined using a Coulter counter as previously described (Stewart et al. 1995, Spicer \& Chamberlain 1998, Spicer et al. 2008), and used to calculate steroid production on an ng or pg per $10^{5}$ cell basis.

To further verify that the effect of $\mathrm{SHH}$ on cell numbers was due to cell proliferation, theca cells from large follicles were cultured for $48 \mathrm{~h}$ in $10 \%$ FCS, serum-starved for $24 \mathrm{~h}$ by culturing in serum-free medium, medium changed, and then cells cultured for an additional $40 \mathrm{~h}$ in serum-free medium with either no treatment, $10 \mathrm{ng} / \mathrm{ml}$ IGF1, $10 \mathrm{ng} / \mathrm{ml}$ IGF1 plus $100 \mathrm{ng} / \mathrm{ml} \mathrm{SHH}$, or $10 \mathrm{ng} / \mathrm{ml}$ IGF1 plus $1000 \mathrm{ng} / \mathrm{ml} \mathrm{SHH}$ in the presence of $1 \mu \mathrm{Ci}$ of ${ }^{3} \mathrm{H}$-thymidine to assess DNA synthesis as previously described (Spicer et al. 2008).

To determine whether PTCH1 mRNA was regulated by hormones, theca cells were obtained from large bovine follicles and cultured for $48 \mathrm{~h}$ in $10 \%$ FCS, followed by treatments arranged in three experiments. The first experiment evaluated the effect of 24-h treatment of insulin $(0$ or $100 \mathrm{ng} / \mathrm{ml})$ and plating density ( 1 or $3 \times 10^{5}$ cells/well) on PTCH1 mRNA. The second and third experiments evaluated the effect of 24-h and 48-h treatment respectively, of IGF1 (0 or $30 \mathrm{ng} / \mathrm{ml}$ ) and/or LH ( 0 or $30 \mathrm{ng} / \mathrm{ml}$ ) on PTCH1 mRNA. After the first $48 \mathrm{~h}$, cells were washed twice with $0.5 \mathrm{ml}$ serum-free medium, and treated for an additional 24 or $48 \mathrm{~h}$ in serum-free medium with the indicated treatments. Cells were then lysed with TRIzol and frozen for later extraction of RNA (see below).

To determine whether $I H H$ mRNA was regulated by hormones, granulosa cells were obtained from small bovine follicles and cultured for $48 \mathrm{~h}$ in $10 \%$ FCS. After the first $48 \mathrm{~h}$, cells were washed twice with $0.5 \mathrm{ml}$ serum-free medium, and treated for an additional $24 \mathrm{~h}$ in serum-free medium with IGF1 (0 or $30 \mathrm{ng} / \mathrm{ml}$ ) and/or FSH (0 or $30 \mathrm{ng} / \mathrm{ml}$ ). Cells were then lysed with TRIzol and frozen for later extraction of RNA (see below).

Bovine theca and granulosa cells were lysed in $0.5 \mathrm{ml} \mathrm{TRIzol}$ Reagent (Life Technologies Inc.), RNA extracted, and RNA quantity determined spectrophotometrically at $260 \mathrm{~nm}$ as previously described (Voge et al. 2004, Spicer et al. 2008). The target gene primers (forward, reverse) and probe sequences for Ihh (Accession XM_601000) were CGGCTTCGACTGGGTGTATTAC, AGGGAAGCAGCCACCTGTCT, CAAGGCCCACGTGCATTGCTCC respectively; for Ptch1 (Accession XM_869803) were TGCCCAGGCTACGAGGACTA, CCGGACATTAAAAGGCACATG, and TGACCACGGCCTGTTTGAGGACC respectively; and for Smo (conserved regions of Accession SM_876452 and XM_586374) were CACCTGCTCACGTGGTCACT, CAAAACAGATGCCGCTCACA, and ACTGTGGCAATCCTCGCCGTGG respectively. The primers that spanned exon-exon junctions were the $I h h$ and Smo primers. Sequences for the LHCGR, CYP11A1, and CYP17A1 primers and probes have been reported (Spicer et al. 2008). A BLAST search (http://www.ncbi.nlm.nih.gov/BLAST) was also conducted to insure the specificity of the designed primers and probe and to assure that they were not designed from any homologous regions coding for other genes.

The differential expression of target gene mRNA in theca and granulosa cells along with 18S rRNA (for normalization of target gene expression) was quantified using the one-step multiplex qRT-PCR for Taqman Gold RT-PCR Kit (Applied Biosystems, Foster City, CA, USA) as previously described
(Voge et al. 2004, Spicer et al. 2008). All samples were run in duplicate. Relative quantification of target gene mRNAs was expressed using the comparative threshold cycle method as previously described (Voge et al. 2004, Aad et al. 2006, Spicer et al. 2008).

\section{Statistical analyses}

Experimental data are presented as least-squares means \pm S.E.M. of measurement from replicated experiments. For rat studies, means were analyzed by one-way ANOVA and t-tests conducted to compare means. For bovine studies, each experiment was replicated three or more times, and within each experiment, treatments were applied in triplicate culture wells. Each experiment was conducted on a separate pool of theca or granulosa cells obtained from five to eight cows or heifers. The main effects and their interactions on the variables measured were assessed by general linear models procedure of SAS (SAS Institute Inc., Cary, NC, USA). To correct for heterogeneity of variance, androstenedione production, Ptch1 mRNA, Ihh mRNA, Smo mRNA, and Gli mRNA were analyzed after transformation natural $\log (x+1)$. Specific differences among treatments were tested using Fisher's protected leastsignificant difference procedure (Ott 1977). Significance was declared at $(P<0.05)$ unless noted otherwise.

\section{Declaration of interest}

The authors declare that there is no conflict of interest that could be perceived as prejudicing the impartiality of the research reported.

\section{Funding}

This work was supported by the NICHD, National Institutes of Health, through Cooperative Agreement U54-HD-31398 as part of the Specialized Cooperative Centers Program in Reproduction Research, and by the National Research Initiative Competitive Grant no. 2005-35203-15334 from the USDA Cooperative State Research, Education, and Extension Service.

\section{Acknowledgements}

We thank D Allen, A Grado, L Hulsey, and D Lagaly at Oklahoma State University for Technical Assistance, the OSU Microarray Core Facility and OSU Recombinant DNA/Protein Resource Facility for use of equipment, Creekstone Farms (Arkansas City, KS) for their generous donations of bovine ovaries, Dr A F Parlow, National Hormone \& Pituitary Program (Torrance, CA, USA) for purified LH, and C Spencer for editorial assistance.

\section{References}

Aad PY, Voge JL, Santiago CA, Malayer JR \& Spicer LJ 2006 Real-time RT-PCR quantification of pregnancy-associated plasma protein-A mRNA abundance in bovine granulosa and theca cells: effects of hormones in vitro. Domestic Animal Endocrinology 31 357-372. 
Aad PY, Echternkamp SE \& Spicer LJ 2008 The hedgehog system in ovarian follicles of cattle selected for twin ovulations and births: evidence of a link between the IGF and hedgehog systems. Biology of Reproduction 78 109-110.

Belaoussoff M, Farrington SM \& Baron MH 1998 Hematopoietic induction and respecification of A-P identity by visceral endoderm signaling in the mouse embryo. Development 125 5009-5018.

Bitgood MJ, Shen L \& McMahon AP 1996 Sertoli cell signaling by desert hedgehog regulates the male germline. Current Biology 6 298-304.

Briggs KJ, Corcoran-Schwartz IM, Zhang W, Harcke T, Devereux WL, Baylin SB, Eberhart CG \& Watkins DN 2008 Cooperation between the Hic1 and Ptch1 tumor suppressors in medulloblastoma. Genes and Development 22 770-785.

Chun SY, Bae HW, Kim WJ, Park JH, Hsu SY \& Hsueh AJ 2001 Expression of messenger ribonucleic acid for the antiapoptosis gene P11 in the rat ovary: gonadotropin stimulation in granulosa cells of preovulatory follicles. Endocrinology 142 2311-2317.

Clark AM, Garland KK \& Russell LD 2000 Desert hedgehog (Dhh) gene is required in the mouse testis for formation of adult-type Leydig cells and normal development of peritubular cells and seminiferous tubules. Biology of Reproduction 63 1825-1838.

Deckelbaum RA, Chan G, Miao D, Goltzman D \& Karaplis AC 2002 Ihh enhances differentiation of CFK-2 chondrocytic cells and antagonizes PTHrP-mediated activation of PKA. Journal of Cell Science $\mathbf{1 1 5}$ 3015-3025.

Dyer MA, Farrington SM, Mohn D, Munday JR \& Baron MH 2001 Indian hedgehog activates hematopoiesis and vasculogenesis and can respecify prospective neurectodermal cell fate in the mouse embryo. Development 128 1717-1730.

Echternkamp SE, Roberts AJ, Lunstra DD, Wise T \& Spicer LJ 2004 Ovarian follicular development in cattle selected for twin ovulations and births. Journal of Animal Science 82 459-471.

Forbes AJ, Lin H, Ingham PW \& Spradling AC 1996 Hedgehog is required for the proliferation and specification of ovarian somatic cells prior to egg chamber formation in Drosophila. Development 122 1125-1135.

Fuse N, Maiti T, Wang B, Porter JA, Hall TM, Leahy DJ \& Beachy PA 1999 Sonic hedgehog protein signals not as a hydrolytic enzyme but as an apparent ligand for patched. PNAS 96 10992-10999.

Ginther OJ, Bergfelt DR, Kulick LJ \& Kot K 2000 Selection of the dominant follicle in cattle: role of two-way functional coupling between folliclestimulating hormone and the follicles. Biology of Reproduction $\mathbf{6 2}$ 920-927.

Goodrich LV, Johnson RL, Milenkovic L, McMahon JA \& Scott MP 1996 Conservation of the hedgehog/patched signaling pathway from flies to mice: induction of a mouse patched gene by hedgehog. Genes and Development 10 301-312.

Goodrich LV, Milenkovic L, Higgins KM \& Scott MP 1997 Altered neural cell fates and medulloblastoma in mouse patched mutants. Science $\mathbf{2 7 7}$ 1109-1113.

Gulino A, Di Marcotullio L, Ferretti E, De Smaele E \& Screpanti I 2007 Hedgehog signaling pathway in neural development and disease. Psychoneuroendocrinology 32 S52-S56.

Hammerschmidt M, Brook A \& McMahon AP 1997 The world according to hedgehog. Trends in Genetics 13 14-21.

Ingham PW \& McMahon AP 2001 Hedgehog signaling in animal development: paradigms and principles. Genes and Development 15 3059-3087.

Ingham PW, Taylor AM \& Nakano Y 1991 Role of the Drosophila patched gene in positional signaling. Nature 353 184-187.

Kenney AM \& Rowitch DH 2000 Sonic hedgehog promotes G(1) cyclin expression and sustained cell cycle progression in mammalian neuronal precursors. Molecular and Cellular Biology 20 9055-9067.

Krishnan V, Ma Y, Moseley J, Geiser A, Friant S \& Frolik C 2001 Bone anabolic effects of sonic/indian hedgehog are mediated by bmp-2/4dependent pathways in the neonatal rat metatarsal model. Endocrinology 142 940-947.

Lee K, Jeong J, Kwak I, Yu CT, Lanske B, Soegiarto DW, Toftgard R, Tsai MJ, Tsai S, Lydon JP et al. 2006 Indian hedgehog is a major mediator of progesterone signaling in the mouse uterus. Nature Genetics 38 1204-1209.

Lum L \& Beachy PA 2004 The Hedgehog response network: sensors, switches, and routers. Science 304 1755-1759.
Di Marcotullio L, Ferretti E, Greco A, De Smaele E, Screpanti I \& Gulino A 2007 Multiple ubiquitin-dependent processing pathways regulate hedgehog/gli signaling: implications for cell development and tumorigenesis. Cell Cycle 15 390-393.

Marigo V, Davey RA, Zuo Y, Cunningham JM \& Tabin CJ 1996 Biochemical evidence that patched is the Hedgehog receptor. Nature 384 176-179.

Marion GB, Gier HT \& Choudary JB 1968 Micromorphology of the bovine ovarian follicular system. Journal of Animal Science 27 451-465.

Matsumoto H, Zhao X, Das SK, Hogan BL \& Dey SK 2002 Indian hedgehog as a progesterone-responsive factor mediating epithelialmesenchymal interactions in the mouse uterus. Developmental Biology 245 280-290.

Ohnishi J, Ohnishi E, Jin M, Hirano W, Nakane D, Matsui H, Kimura A, Sawa H, Nakayama K, Shibuya H et al. 2001 Cloning and characterization of a rat ortholog of MMP-23 (matrix metalloproteinase-23), a unique type of membrane-anchored matrix metalloproteinase and conditioned switching of its expression during the ovarian follicular development. Molecular Endocrinology 15 747-764.

Ott L, (Ed). 1977 An Introduction to Statistical Methods and Data Analysis. North Scituate, MA: Duxbury Press.

Owens GE, Keri RA \& Nilson JH 2002 Ovulatory surges of human CG prevent hormone-induced granulosa cell tumor formation leading to the identification of tumor-associated changes in the transcriptome. Molecular Endocrinology 16 1230-1242.

Park SY, Tong M \& Jameson JL 2007 Distinct roles for steroidogenic factor 1 and desert hedgehog pathways in fetal and adult Leydig cell development. Endocrinology 148 3704-3710.

Pathi S, Pagan-Westphal S, Baker DP, Garber EA, Rayhorn P, Bumcrot D, Tabin CJ, Blake Pepinsky R \& Williams KP 2001 Comparative biological responses to human Sonic, Indian, and Desert hedgehog. Mechanisms of Development 106 107-117.

Pierucci-Alves F, Clark AM \& Russell LD 2001 A developmental study of the Desert hedgehog-null mouse testis. Biology of Reproduction 65 1392-1402.

Russell MC, Cowan RG, Harman RM, Walker AL \& Quirk SM 2007 The hedgehog signaling pathway in the mouse ovary. Biology of Reproduction 77 226-236.

Spicer LJ \& Chamberlain CS 1998 Influence of cortisol on insulin-like growth factor I (IGF-I)-induced steroid production and on IGF-I receptors in cultured bovine granulosa cells and thecal cells. Endocrine 9 153-161.

Spicer LJ \& Francisco CC 1997 The adipose obese gene product, leptin: evidence of a direct inhibitory role in ovarian function. Endocrinology 138 3374-3379.

Spicer LJ, Convey EM, Leung K, Short RE \& Tucker HA 1986 Anovulation in postpartum suckled beef cows. II. Associations among binding of 125Ilabeled gonadotropins to granulosa and thecal cells, and concentrations of steroids in serum and various sized ovarian follicles. Journal of Animal Science $62742-750$

Spicer LJ, Chamberlain CS \& Morgan GL 2001 Proteolysis of insulin-like growth factor binding proteins during preovulatory follicular development in cattle. Domestic Animal Endocrinology 21 1-15.

Spicer LJ, Chamberlain CS \& Maciel SM 2002 Influence of gonadotropins on insulin- and insulin-like growth factor-I (IGF-I)-induced steroid production by bovine granulosa cells. Domestic Animal Endocrinology 22 237-254.

Spicer LJ, Aad PY, Allen DT, Mazerbourg S, Payne AH \& Hsueh AJ 2008 Growth differentiation factor 9 (GDF9) stimulates proliferation and inhibits steroidogenesis by bovine theca cells: influence of follicle size on responses to GDF9. Biology of Reproduction 78 243-253.

Stewart RE, Spicer LJ, Hamilton TD \& Keefer BE 1995 Effects of insulin-like growth factor I and insulin on proliferation and on basal and luteinizing hormone-induced steroidogenesis of bovine thecal cells: involvement of glucose and receptors for insulin-like growth factor I and luteinizing hormone. Journal of Animal Science 73 3719-3731.

Stewart RE, Spicer LJ, Hamilton TD, Keefer BE, Dawson LJ, Morgan GL \& Echternkamp SE 1996 Levels of insulin-like growth factor (IGF) binding proteins, luteinizing hormone and IGF-I receptors, and steroids in dominant follicles during the first follicular wave in cattle exhibiting regular estrous cycles. Endocrinology 137 2842-2850. 
St-Jacques B, Hammerschmidt M \& McMahon AP 1999 Indian hedgehog signaling regulates proliferation and differentiation of chondrocytes and is essential for bone formation. Genes and Development 13 2072-2086.

Stone DM, Hynes M, Armanini M, Swanson TA, Gu Q, Johnson RL, Scott MP, Pennica D, Goddard A, Phillips H et al. 1996 The tumoursuppressor gene patched encodes a candidate receptor for Sonic hedgehog. Nature 384 129-134.

Taipale J, Cooper MK, Maiti T \& Beachy PA 2002 Patched acts catalytically to suppress the activity of Smoothened. Nature 418 892-897.

Takamoto N, Zhao B, Tsai SY \& DeMayo FJ 2002 Identification of Indian hedgehog as a progesterone-responsive gene in the murine uterus. Molecular Endocrinology 16 2338-2348.

Traiffort E, Charytoniuk DA, Faure H \& Ruat M 1998 Regional distribution of Sonic Hedgehog, patched, and smoothened mRNA in the adult rat brain. Journal of Neurochemistry 70 1327-1330.

Voge JL, Aad PY, Santiago CA, Goad DW, Malayer JR \& Spicer LJ 2004 Effect of insulin-like growth factors (IGF), FSH, and leptin on IGFbinding-protein mRNA expression in bovine granulosa and theca cells: quantitative detection by real-time PCR. Peptides 25 2195-2203.

Vortkamp A, Lee K, Lanske B, Segre GV, Kronenberg HM \& Tabin CJ 1996 Regulation of rate of cartilage differentiation by Indian hedgehog and PTH-related protein. Science 273 613-622.
Wang Y, McMahon AP \& Allen BL 2007 Shifting paradigms in Hedgehog signaling. Current Opinion in Cell Biology 19 159-165.

Wijgerde M, Ooms M, Hoogerbrugge JW \& Grootegoed JA 2005 Hedgehog signaling in mouse ovary: Indian hedgehog and desert hedgehog from granulosa cells induce target gene expression in developing theca cells. Endocrinology 146 3558-3566.

Yao HH, Whoriskey W \& Capel B 2002 Desert Hedgehog/Patched 1 signaling specifies fetal Leydig cell fate in testis organogenesis. Genes and Development 16 1433-1440.

Zhang Y \& Kalderon D 2000 Regulation of cell proliferation and patterning in Drosophila oogenesis by hedgehog signaling. Development 127 2165-2176.

Zhang XM, Ramalho-Santos M \& McMahon AP 2001 Smoothened mutants reveal redundant roles for Shh and Ihh signaling including regulation of L/R asymmetry by the mouse node. Cell 105 781-792.

Received 24 July 2008

First decision 11 September 2008

Revised manuscript received 11 April 2009

Accepted 11 May 2009 